\title{
Criminal Careers Prior to Recruitment into Italian Organized Crime
}

\author{
Cecilia Meneghini \\ Gian Maria Campedelli \\ Francesco Calderoni \\ Tommaso Comunale
}

Aug 10, 2021

Notice: This is the authors' accepted manuscript of Meneghini, C., Campedelli, G. M., Calderoni, F., \& Comunale, T. (2021). Criminal Careers Prior to Recruitment into Italian Organized Crime: Crime \& Delinquency. https://doi.org/10.1177/00111287211035994

\section{License: Creative Commons Attribution-NonCommercial-NoDerivatives 4.0 International (CC BY-NC-ND 4.0)}

\begin{abstract}
Despite growing evidence about heterogeneous pathways leading individuals into organized crime, there is limited knowledge about the differences in the criminal career between individuals who entered criminal organizations in their youth and those who joined at an older age. This study assesses the differences between early and late recruits in the Italian mafias through logistic regressions considering several criminal career parameters computed on the period prior to recruitment. Results show that recruitment in the mafias is far from a homogenous process. Early recruits report an early criminal onset, lower educational attainment, more serious offenses within a shorter time-span, and more frequent violent co-offending; late recruits show a later onset, more prolific and versatilebut less serious-offending.
\end{abstract}

\section{Introduction}

Involvement in social groups is frequently a gradual process possibly taking years; and joining an organized crime group is no exception. While there is growing evidence about 
the criminogenic and negative turning-point effects of joining such groups, less is known about what factors and criminal careers lead to recruitment (Campedelli et al., 2019; Comunale et al., 2020; Melde \& Esbensen, 2011). Until twenty years ago, scholars devoted most of their attention to recruitment into juvenile street gangs. Now available are several systematic reviews summarizing the existing evidence on the relative strength of various factors (Higginson et al., 2018; Pyrooz et al., 2016; Raby \& Jones, 2016) and the effects of specific interventions (Higginson et al., 2015; Hodgkinson et al., 2009; Klein \& Maxson, 2006). Since the terrorist attacks of the early 2000s, also terrorism research has started to focus on radicalization as a process that may lead to involvement in violent extremism and terrorism (McGilloway et al., 2015; Wolfowicz et al., 2019). Much less systematic has been theoretical and empirical research on recruitment into organized crime; research which, despite the broadness of the concept and definitional problems (Hagan, 2006; Maltz, 1976; D. C. Smith, 1975; Varese, 2017; Von Lampe, 2016), normally excludes juvenile street gangs and terrorism (Decker \& Pyrooz, 2014; Desmond \& Hussain, 2017).

The involvement in organized criminal groups has received limited scholarly attention. This is primarily due to a lack of reliable data (see Hobbs \& Antonopoulos, 2014; Kemp et al., 2019) and the need to combine quantitative and qualitative methods (Kleemans \& Van Koppen, 2020). Comunale et al. (2020) conducted a systematic review of the factors leading to recruitment into organized crime and found that only a minority of the empirical studies analyzed directly addressed the topic of recruitment (e.g., Kleemans \& De Poot, 2008; Van Koppen \& De Poot, 2013); in the majority of cases, indications on recruitment were derived as collateral results from studies with different objectives (e.g., comparing offending levels between organized crime members and the general population) (e.g., Kirby et al., 2016; Van Koppen, De Poot, \& Blokland, 2010). Studies on recruitment have emphasized social relations and criminal skills among the main factors leading individuals into organized crime. Furthermore, the literature has pointed out that these factors may differently affect individual mechanisms of involvement, so that there are multiple pathways into criminal organizations (Kemp et al., 2019; Kleemans \& De Poot, 2008; Kleemans \& Van Koppen, 2020; R. G. Smith, 2014).

Within this context, evidence about heterogeneous offending trajectories, a higher proportion of late onset offenders, and an average age of recruitment well into the late twenties and thirties raise interesting challenges against consolidated theoretical explanations of crime, which are mostly based on high-volume crime and samples comprising adolescents and youths (Kleemans \& Van Koppen, 2020). Yet, the extant research has rarely systematically assessed what factors lead to an early, or late, recruitment into organized crime. Besides filling a relevant gap in the current knowledge on organized crime involvement, understanding the distinctive pathways leading to recruitment at different ages is a necessary step towards developing targeted prevention policies based on the criminal risk factors identified.

This study addresses this gap by comparing early and late recruits into the Italian mafias. The analysis relies on the largest available sample of organized crime offenders, which comprises more than 150,000 final criminal convictions of 9,994 individuals. Using logistic regressions, we assess the differences between early recruits and late recruits across several criminal career parameters computed on the period before their first mafia 
association offense. Our findings confirm that recruitment into mafias exhibits different patterns for younger and older recruits: early recruits record an early criminal onset, lower educational attainment, more serious offenses within a shorter time-span, and more frequent violent co-offending; late recruits show a later onset, more prolific and versatile but less serious - offending. The results are robust to different subsamples and thresholds for the identification of early/late recruits, and they imply that policies aimed at preventing organized crime recruitment must be differentiated according to the specific factors leading to recruitment at different ages.

\section{Background}

\section{Main factors affecting recruitment to organized crime}

A substantial body of research has shown that different social relations lead individuals into criminal organizations (Kemp et al., 2019; Kleemans \& De Poot, 2008; Kleemans \& Van de Bunt, 1999; Kleemans \& Van Koppen, 2014). First, family and kinship ties may drive recruitment into organized crime. While this may be unsurprising for complex and traditional mafia organizations (Albini, 1971; Brancaccio, 2017; Catino, 2019, 2020; Gambetta, 1993; Ianni \& Reuss-Ianni, 1972; Paoli, 2003; Sergi, 2016), more recent studies have shown the importance of the inter-generational transmission of criminal behavior also within Dutch criminal families (Spapens \& Moors, 2020; Van Dijk et al., 2019). Second, organized crime more frequently recruits individuals with a shared ethnic, country, or neighborhood background, as well as through general friendship relations and acquaintances (Albini, 1971; Paoli, 2003; Van Koppen, 2013). Lastly, work relations may open opportunities for involvement in organized crime (Kleemans \& De Poot, 2008; Steffensmeier \& Ulmer, 2005; Van Koppen \& De Poot, 2013).

In addition to social relations, criminal and criminally exploitable skills are important factors leading to recruitment into organized crime (Comunale et al., 2020). These skills comprise the capacity to use violence (Blokland et al., 2019; Gambetta, 1993; Requena et al., 2014), to adhere to the code of silence, and to avoid police detection (Densley, 2013; Gambetta, 1993), as well as criminally exploitable skills acquired through formal education, training, and/or jobs (Salinas \& Regadera, 2016; Van Koppen \& De Poot, 2013). While the literature has pointed out the existence of various pathways and the importance of social relations and criminal skills, much less is known about how these factors - and their interactions - influence the age of recruitment into organized crime. Some studies and theories have explained pathways to the recruitment of relatively young offenders (e.g., Arlacchi, 1983; Ciconte, 1992; Ostrosky et al., 2012), while others have focused on organized crime recruitment of adult-onset offenders (e.g., Kleemans \& De Poot, 2008; Salinas \& Regadera, 2016), but to the best of our knowledge no previous research has attempted to compare the various factors leading to an early as opposed to a late recruitment age.

Some individuals may join a criminal group at a relatively young age through multiple mechanisms. First, from a life-course perspective, early starters may be at a higher risk of becoming involved in serious and violent offending (Higginson et al., 2018; Loeber et al., 
2003; Raby \& Jones, 2016). Early onset may lead to organized crime-related offenses and eventually recruitment, especially for individuals embedded in crime-prone social relations (Van Dijk et al., 2019). Second, social learning, differential association, and cultural influences within kinship relations may facilitate involvement in the group at a very young age (Paoli, 2003; Sergi, 2018; Spapens \& Moors, 2020). Kinship may also favor recruitment due to its capacity to increase mutual trust and prevent defection (Campana \& Varese, 2013). Third, co-offending - particularly violent co-offending - may combine individualcriminal and social-relational mechanisms. According to the signaling theory, criminal groups need to overcome information asymmetry when involving others by establishing whether prospective members of the group can be trusted and are 'criminally valuable' (Gambetta, 2009, 2011; Pyrooz \& Densley, 2016). Prospective members may engage in violent and serious offenses in order to signal a credible commitment to the group, or it may even be part of the criminal training of youngsters embedded in crime-prone social relations. Co-offending may be the most effective way to prove trustworthiness and capacity. It may also reinforce mutual trust by revealing information about recruits (Campana \& Varese, 2013), and reflect learning dynamics whereby young offenders are taught that violence should be seen as not only acceptable but also valued (Conway \& McCord, 2002).

Other individuals may join organized criminal groups later in life due to specific skills, relations, and professional characteristics which can be acquired only during adulthood (Kleemans \& De Poot, 2008; Van Koppen, De Poot, \& Blokland, 2010). The mafias exploit profitable social ties when they need to recruit offenders who have specific professional expertise gained in either criminal or legitimate settings (Arlacchi, 1983; Behan, 1996; Cressey, 1969; Gambetta, 1993; Hess, 1993). Independent entrepreneurs, financial and legal experts, and individuals employed in the transport industry are among the professionals most valuable for organized criminal groups (Kleemans \& De Poot, 2008; Van Koppen \& De Poot, 2013). The literature refers to the concepts of 'social embeddedness' and 'social opportunity structure' to define the role of social ties and opportunities in providing access to criminal opportunities within organized crime (Kleemans \& De Poot, 2008; Kleemans \& Van de Bunt, 1999). Individuals recruited at a later age may report no previous criminal records or late onset (Campedelli et al., 2019; Van Koppen, De Poot, \& Blokland, 2010). They may show greater specialization in specific types of crimes or specific knowledge and professional abilities acquired through higher education (Brancaccio, 2017; Kleemans \& De Poot, 2008; Van der Geest et al., 2020; Van Koppen \& De Poot, 2013).

\section{Criminal trajectories of organized crime offenders}

Empirical findings show that, on average, recruitment into organized crime occurs during adulthood. For example, Van Koppen and colleagues examined 746 Dutch organized crime offenders and found that they had committed their criterion offense at an average age of 39 years (2010, p. 262). A more recent update on 1,921 offenders showed an average age of 38 (Van der Geest et al., 2020). Klement studied 297 Danish outlaw bikers, who were approximately 28 years old when registered in the police gang database (2016a, p. 459, 2016b). Blokland and colleagues analyzed 601 Dutch outlaw bikers active between 2007 
and early 2013, finding that most individuals were 35 years old or older in 2013 (2019). Similarly, Morgan and colleagues studied 5,669 individuals affiliated with different outlaw motorcycle clubs and chapters in the Australian National Gang List, reporting an average age per gang ranging between 33 and 58 years old (Morgan et al., 2020, p. 6). Campedelli and colleagues showed that the average age when the first mafia offense was committed among 11,138 Italian mafia offenders was approximately 34 years old (2019). However, the same studies acknowledged pathways of involvement at different ages. The relatively high average age at recruitment exhibits a significant variance encompassing different moments of involvement and criminal trajectories.

Research has also demonstrated that organized crime offenders have higher levels of offending throughout their lifetimes and even before the hypothesized time of recruitment compared to non-organized-crime offenders (Blokland et al., 2019; Kirby et al., 2016; Kleemans \& Van Koppen, 2020; Pedersen, 2018; Sharpe, 2002; Van Koppen, De Poot, \& Blokland, 2010). Whereas the difference with respect to general offenders is intuitive, research on the differences among organized crime offenders is still unclear. Some studies have applied group-based trajectory modeling to organized crime offenders and revealed different criminal trajectories (Campedelli et al., 2019; Francis et al., 2013; Morgan et al., 2018; Van Koppen, De Poot, Kleemans, et al., 2010). A significant proportion of offenders report a late onset, suggesting absent (or undetected) criminal activity during youth and later involvement in criminal groups (Kleemans \& Van Koppen, 2020). Yet all studies have found trajectories of early-starters, prolific and violent offenders (Campedelli et al., 2019; Francis et al., 2013; Kirby et al., 2016; Van Koppen, De Poot, Kleemans, et al., 2010). In conclusion, whilst prior research has theorized and seldom identified different pathways into organized crime, no prior study has systematically examined the factors leading to early or late recruitment into organized crime.

\section{Current study}

This study quantitatively compares the criminal career prior to recruitment of individuals who entered the Italian mafias at a relatively early age with respect to those who joined the mafias at a considerably later stage. The focus on the Italian mafias is justified by the fact that a criminal group of this type is often regarded as the epitome of organized crime (Paoli, 2014), and we were granted access to a large and comprehensive data set on the criminal careers of Italian mafia offenders, who exhibit a significant variance in their recruitment ages. Taking into consideration the identified research gap, we address two main research questions:

Research Question 1: Do offenders who experience early recruitment into organized crime exhibit significant differences in their criminal careers prior to recruitment in comparison to offenders recruited at a later age?

Research Question 2: What are the pre-recruitment factors leading to early as opposed to late recruitment into organized crime?

With respect to the first research question, we hypothesize that early and late organized crime recruits present significant differences in their criminal careers before recruitment. With respect to the second research question, and based on the review above, we posit that 
early onset, violence, co-offending, and lower education may lead to early recruitment and that late onset, less violent offending, specialization, and higher education may lead to a later organized crime recruitment.

\section{Data and methods}

\section{Sample selection}

The analysis relied on the Proton Mafia Members (PMM) data set, 1 which contains information on the entire criminal careers of 11,138 offenders convicted in Italy for at least one mafia offense from 1985 to 2017. A final conviction for a mafia offense - addressed by specific provisions in the Italian criminal legislation2 - was the criterion for inclusion in the sample, but offenders committed a variety of other crime types. The data set was created from original data provided by the Italian Ministry of Justice and made it possible to precisely reconstruct the sequence of crimes committed by each individual. The PMM data set includes data on all final criminal convictions (e.g., year of commission, year of conviction, violated provision, co-offending) along with relevant sociodemographic variables (e.g., the offender's year of birth or educational qualifications). For mafia offenses, the year of the first commission can be used as a proxy for the year the individual joined the criminal organization. The availability of this information, coupled with the significant variation in the observed age at first mafia offense in the sample, provides an opportunity to analyze the criminal careers leading to recruitment at different ages. The results may then be used to understand the factors affecting recruitment at comparable ages into other types of organized criminal groups. We derived information on the type 3 and seriousness of each offense, the latter being computed as the average between the maximum and minimum statutory penalty (measured in months of imprisonment) set by the Italian legislation (more detailed information on the data set is available in the Supplementary Materials, and in Campedelli et al. (2019)).4

From the original 11,138 offenders in the data set, we removed offenders who had committed their first mafia offense before the end of 1987. The offense of 'mafia association' was introduced into the Italian Criminal Code in 1982. It is likely that criminal proceedings initiated immediately after the introduction of the offense ascribed the crime to 1982 or the years immediately afterwards for prosecutorial strategies, e.g. because conducts before 1982 would not be punishable. Given that our data indicated that the lag between the year of crime commission and the year of conviction for mafia association is on average 6 years, we decided to exclude offenders convicted within 6 years after the introduction of the mafia association offense. Our final sample comprised 9,994 offenders born between 1927 and 1994, and who had committed their first mafia association offense in or after 1988 (see the Supplementary Materials for additional information on the possible bias caused by the response of the judicial system).

\section{Dependent variables}

We created two different dependent dummy variables: 'early recruit' and 'late recruit'. An offender's assignment to one of the two groups depended on the age at first mafia offense 
(mean $=34.69, \mathrm{SD}=10.58$, see Figure 1, left panel). Early recruits are offenders who committed their first mafia offense at age 26 or younger $\left(20^{\text {th }}\right.$ percentile of the distribution of the age at first mafia offense). Conversely, late recruits are individuals whose first mafia offense has been at age 43 or older ( $80^{\text {th }}$ percentile). The thresholds capture very different offenders in terms of their recruitment age, thus favoring the identification of differences between early/late recruits and the rest of the sample.

Reliance on the age of crime commission reported in the PMM may result in possible biases. First, like most studies on the career of organized crime offenders, we relied on official crime records and particularly on final convictions. The inherent dark number problem may bias our identification of the recruitment age, especially for late recruits. Involvement in mafias is probably a long process that may occur well before the offense is discovered and prosecuted. However, the average recruitment age is in line with the abovereviewed literature pointing out that involvement in organized crime occurs in adulthood. Furthermore, a substantial body of qualitative research has confirmed that organized crime offenders join organized crime well into adulthood and have very limited prior involvement with the criminal justice system; and it argues that these patterns are not a mere consequence of unrecorded crimes (e.g., Kleemans \& De Poot, 2008; Van der Geest et al., 2020; Van Koppen \& De Poot, 2013). Notwithstanding these reassuring findings from the previous literature, we acknowledge that the year of the first recorded mafia offense identifies the moment in which involvement in organized crime is first known to the police, rather than being the actual time of recruitment, and that this is an important limitation of our analysis. For this reason, throughout the text, we use the terms 'recruitment' and 'involvement' in organized crime as proxies for the actual timing of involvement in the criminal group. We note that similar approaches are common in the literature (Blokland et al., 2019; Kleemans \& De Poot, 2008; Klement, 2016a; Pedersen, 2018; Van Koppen, De Poot, \& Blokland, 2010; Van Koppen, De Poot, Kleemans, et al., 2010). To the best of our knowledge, the possible inherent biases have never been studied or addressed with specific approaches.

Second, our data comprised 9,994 offenders belonging to different generations, and we expected this to impact on recruitment and criminal careers (Campedelli et al., 2019). The Italian criminal justice system's reaction against mafia offenders has grown progressively more intense since 1982. Figure 1 (right panel) shows clear generational differences between early and late mafia recruits. They are due to two concurrent mechanisms. On the one hand, offenders born in earlier decades faced intense enforcement action later in life (La Spina, 2004, 2014). Hence, the law enforcement may have overlooked early-recruited older offenders. On the other hand, offenders born more recently cannot be late recruits by definition (they were too young in 2017, the time at which the data were extracted). To address these issues, we controlled for the year of birth in all the models, and we checked the robustness of the analysis by restricting the sample to offenders born between 1962 and 1970, a period when there is overlap in the distributions of early and late recruits born in the same years. Lastly, another bias may be caused by the threshold selection for early and late recruits. We tested the sensitivity of the results by means of additional models relying on the $15^{\text {th }}$ and $25^{\text {th }}$ percentile for early recruits and on the $85^{\text {th }}$ and $75^{\text {th }}$ for late recruits, respectively. 
Age at first mafia offence

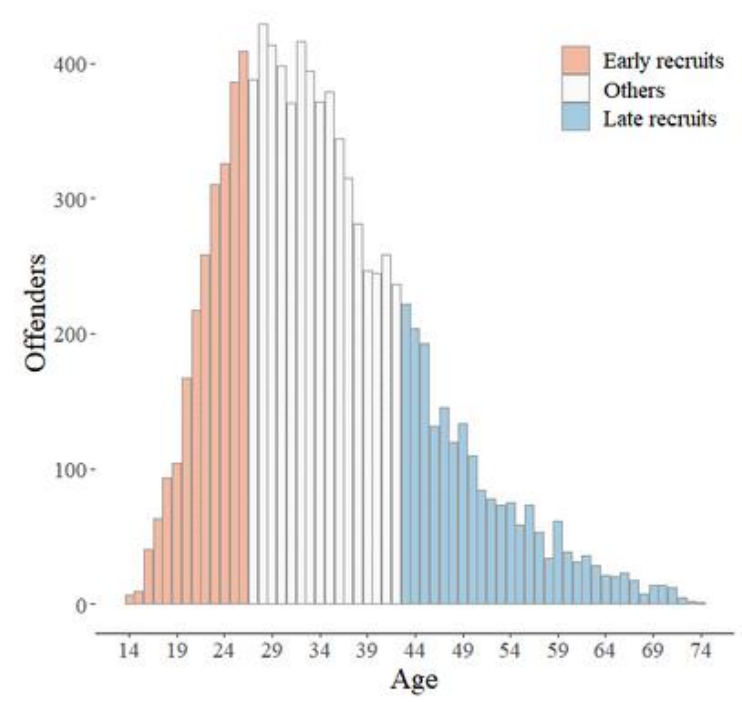

Year of birth by early/late recruit

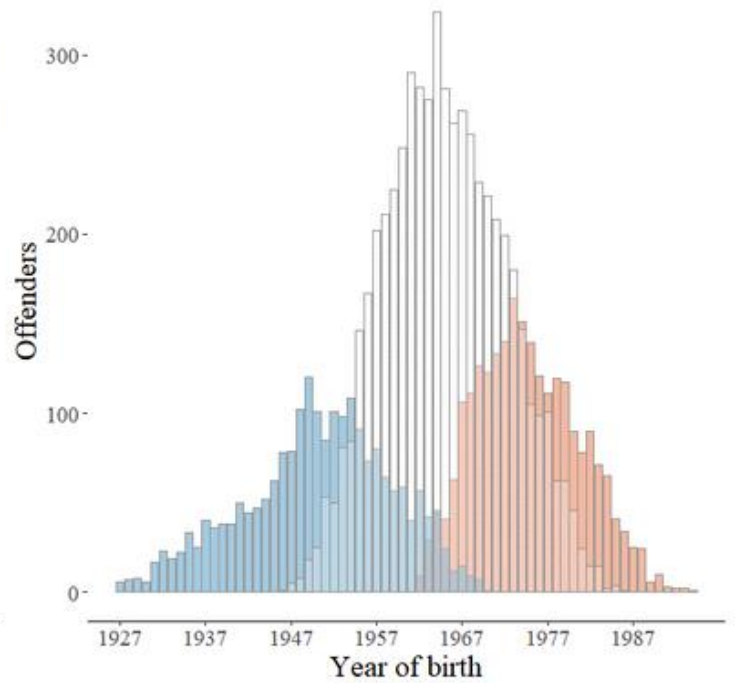

Chart, histogram Description automatically generated

Figure 1. Distribution of the age at first mafia offense (left pane) and of early and late recruits by year of birth (right pane) $(n=9,994)$.

\section{Independent variables}

In all models, we assessed the impact of the onset age on early and late recruitment, and we controlled for the year of birth. The onset age is one of the most discussed concepts in lifecourse criminology, not only within organized crime research (Eggleston \& Laub, 2002; Farrington et al., 2014; Nagin \& Farrington, 1992; Slade et al., 2008; Tremblay et al., 1999). Furthermore, organized crime samples often report a significant proportion of late onset offenders (Kleemans \& Van Koppen, 2020). The offender's year of birth controlled for the generational differences mentioned in the previous subsection. To improve interpretation, the variable was scaled so that it started at 0 for the first year of birth in the sample (1927) and progressively increased (year of birth of individual $i$ minus 1927).

We computed several criminal career parameters. Given our interest in the factors leading to early or late recruitment, we focused on the 'pre-mafia' career, i.e. the offenders' active criminal career preceding their first mafia offense.5 For each offender, we considered the number of crimes committed, their average seriousness, and a measure of specialization, i.e. the tendency to commit crimes of the same type. We computed pre-mafia specialization through the diversity index (Piquero et al., 1999; Sullivan et al., 2006; Wright et al., 2008).6 This measure can be interpreted as the probability that any two offenses drawn randomly from an individual's set of offenses belong to two different crime categories (Piquero et al., 1999). The last pre-mafia parameter was the escalation, the tendency of offenders to move to more serious offense types throughout their criminal careers (Blumstein et al., 1986). Following Liu et al. (2011), we computed the escalation as the coefficient of a linear 
regression of crime seriousness on a temporal measure. We used as the temporal measure the progressive number of offenses committed by the individual prior to their first mafia offense, thus focusing on the experiential process of offenders committing an increasing number of crimes.7

Given the importance of violence and co-offending for recruitment into the mafias (Savona et al., 2017), we grouped all "murder", "robbery", and "assault and violent" offenses in order to compute the number of violent offenses prior to recruitment. We decided to focus on the impact of engaging in violence on the recruitment age because violence is a prominent feature of mafia activities (Arlacchi, 1994; Blok, 1975; Gambetta, 2009), and it is especially important in the context of group crime since it is facilitated by the presence of co-offenders (Conway \& McCord, 2002; Lantz, 2019; McGloin \& Piquero, 2009). Moreover, recent research on gangs has analyzed the variation of violence among gang members in order to understand the different reasons for joining a gang (Wu et al., 2021). We also used two measures of pre-mafia co-offending behavior by computing the share of pre-mafia cooffenses and the number of pre-mafia violent co-offenses. Lastly, we included a variable measuring offenders' education level as registered on their entrance in the penitentiary. The variable was coded as a dummy equal to 1 if the offender had a high school diploma or higher education qualification, and as 0 otherwise.

For all the independent variables (except education), we coded a value of 0 for offenders without a pre-mafia career. For approximately $16 \%$ of the whole sample, the first conviction was a mafia conviction or had occurred in the same year as a mafia conviction. This coding may be problematic for specialization, escalation, and co-offending variables, for which a 0 value has a precise meaning. For this reason, in all models we included a dummy variable that took the value of 1 for offenders who had an active criminal career prior to their recruitment, and 0 otherwise. This variable enabled exploration of whether the absence of a pre-mafia career impacts on the probability of being an early or a late recruit.

\section{Model specification}

To investigate our hypotheses, we relied on logistic regression as the most suitable method with which to capture differences between dichotomous variables mapping whether an individual was either an early or a late recruit.8 We first ran two main sets of models (one for early and one for late recruits), each including four specifications. All regressions included a dummy for whether the individual had an active criminal career before recruitment, the offender's year of birth, onset age, education dummy, the number of premafia crimes, the diversity index, and the escalation of offenses in the pre-mafia career. The first two specifications measured the gravity of crimes committed before recruitment in two different ways (the first model with the average seriousness and the second with the number of violent offenses), both including a measure of co-offending (the share of offenses committed in cooperation with others). In the third specification, we included the number of violent co-offenses to consider the interaction between violence and cooffending. Different studies have highlighted that the presence of co-offenders and the violent nature of the crime are correlated features of the offense primarily because cooffenders facilitate the commission of violent crimes (Conway \& McCord, 2002; Lantz, 
2019; Lantz \& Kim, 2019; McCord \& Conway, 2002; McGloin \& Piquero, 2009). Lastly, we present a fourth specification which excluded the education level of each individual in order to verify whether the results were driven by missing observations for the education variable.

We also verified the robustness of the results by means of additional models. Firstly, we replicated the main models on the subsample of offenders born between 1962 and 1970 . Secondly, we ran the third specification of the main models on the subsample including all individuals with at least two offenses before mafia recruitment, to control whether the findings were biased by offenders who did not have an active pre-mafia career. Lastly, we tested the sensitivity of the models to changes in the classification for early and late recruits by setting the thresholds at $15^{\text {th }}$ and $25^{\text {th }}$ percentile for early recruits, and $85^{\text {th }}$ and $75^{\text {th }}$ percentile for late recruits, respectively.

\section{Results}

\section{Differences between early and late recruits}

Table 1 addresses our first research question, i.e. whether early and late organized crime recruits present significant differences in their criminal careers before recruitment. The statistically significant differences for the majority of the considered independent variables support the hypothesis that there exist several dissimilarities between early and late recruits in their pathways to recruitment. Offenders who experienced early mafia recruitment started to offend earlier and committed fewer, more serious, and less diverse crimes prior to recruitment compared to offenders who joined the mafia group at a later age. While committing fewer offenses before recruitment, early recruits exhibited a higher frequency because they committed on average between 1 and 2 offenses in each year before recruitment (approximately three times the frequency of late recruits). A larger percentage of these offenses were violent and committed in cooperation with other offenders. Moreover, only 10 percent of these early recruits had completed high school, compared to 14 percent of late recruits. 
Table 1. Mean and standard deviation (in square brackets) of the independent variables for the whole sample, early recruits and late recruits $(n=9,994)$.

\begin{tabular}{|c|c|c|c|c|}
\hline Variable & $\begin{array}{l}\text { Whole } \\
\text { sample }\end{array}$ & $\begin{array}{c}\text { Missing (whole } \\
\text { sample, \%) }\end{array}$ & $\begin{array}{l}\text { Early } \\
\text { recruits }\end{array}$ & $\begin{array}{c}\text { Late } \\
\text { recruits }\end{array}$ \\
\hline \multirow{2}{*}{ Onset age * } & 24.01 & 0 & 19.42 & 31.41 \\
\hline & {$[8.70]$} & & {$[2.90]$} & [13.06] \\
\hline Year of birth * & $\begin{array}{c}1964 \\
{[10.98]}\end{array}$ & 0 & $\begin{array}{l}1975 \\
{[6.09]}\end{array}$ & $\begin{array}{l}1950 \\
{[8.66]}\end{array}$ \\
\hline Dummy for active pre-mafia career * & $\begin{array}{c}0.84 \\
{[0.36]}\end{array}$ & 0 & $\begin{array}{c}0.75 \\
{[43.57]}\end{array}$ & $\begin{array}{c}0.85 \\
{[0.36]}\end{array}$ \\
\hline Length of active pre-mafia career * & $\begin{array}{l}10.68 \\
{[9.48]}\end{array}$ & 0 & $\begin{array}{c}3.35 \\
{[2.94]}\end{array}$ & $\begin{array}{c}19.31 \\
{[12.70]}\end{array}$ \\
\hline Number of committed crimes & $\begin{array}{c}15.24 \\
{[15.72]}\end{array}$ & 0 & $\begin{array}{c}15.09 \\
{[14.53]}\end{array}$ & $\begin{array}{c}12.88 \\
{[16.33]}\end{array}$ \\
\hline Number of crimes committed pre-mafia * & $\begin{array}{c}8.91 \\
{[11.37]}\end{array}$ & 0 & $\begin{array}{c}5.78 \\
{[7.75]}\end{array}$ & $\begin{array}{c}9.66 \\
{[14.07]}\end{array}$ \\
\hline Pre-mafia frequency* & $\begin{array}{c}0.96 \\
{[1.36]}\end{array}$ & 0 & $\begin{array}{c}1.44 \\
{[1.94]}\end{array}$ & $\begin{array}{c}0.47 \\
{[0.63]}\end{array}$ \\
\hline Share of co-offenses pre-mafia * & $\begin{array}{l}43.26 \\
{[0.36]}\end{array}$ & 0 & $\begin{array}{c}43.14 \\
{[38.97]}\end{array}$ & $\begin{array}{c}33.23 \\
{[33.03]}\end{array}$ \\
\hline Avg seriousness pre-mafia * & $\begin{array}{c}45.29 \\
{[43.52]}\end{array}$ & 1.22 & $\begin{array}{c}42.41 \\
{[45.97]}\end{array}$ & $\begin{array}{c}37.35 \\
{[41.18]}\end{array}$ \\
\hline Pre-mafia specialization (diversity index) ${ }^{*}$ & $\begin{array}{l}50.81 \\
{[0.33]}\end{array}$ & 0 & $\begin{array}{c}41.50 \\
{[34.49]}\end{array}$ & $\begin{array}{c}50.00 \\
{[33.45]}\end{array}$ \\
\hline Pre-mafia escalation & $\begin{array}{c}10.66 \\
{[53.05]}\end{array}$ & 9.25 & $\begin{array}{c}11.15 \\
{[62.55]}\end{array}$ & $\begin{array}{c}8.26 \\
{[45.42]}\end{array}$ \\
\hline Number of violent offenses pre-mafia * & $\begin{array}{c}1.84 \\
{[0.17]}\end{array}$ & 0 & $\begin{array}{c}1.31 \\
{[2.54]}\end{array}$ & $\begin{array}{c}1.49 \\
{[3.46]}\end{array}$ \\
\hline Number of violent co-offenses pre-mafia * & $\begin{array}{c}1.02 \\
{[0.14]}\end{array}$ & 0 & $\begin{array}{c}0.80 \\
{[1.95]}\end{array}$ & $\begin{array}{c}0.69 \\
{[2.71]}\end{array}$ \\
\hline Dummy for high school or higher education * & $\begin{array}{c}0.13 \\
{[0.34]}\end{array}$ & 17.40 & $\begin{array}{c}0.10 \\
{[0.30]}\end{array}$ & $\begin{array}{c}0.14 \\
{[0.35]}\end{array}$ \\
\hline $\mathrm{N}$ & 9,994 & & 2,389 & 2,122 \\
\hline
\end{tabular}

Note: * statistically significant (at the 5 per cent level) difference in means between early and late recruits (outcome of $t$ tests).

\section{Pre-recruitment characteristics of early and late recruits}

We addressed our second research question - understanding what factors lead to early or late organized crime recruitment - through logistic regressions. Regression results confirmed the existence of significant differences in the criminal careers prior to recruitment between early recruits (aged less than 27 years old) and late ones (aged more than 42 years old) (Table 2). An early onset age is a strong predictor of early recruitment: a delay of one year in the onset age is associated with an approximately $37 \%$ decrease in the likelihood of committing the first mafia offense before the age of 27, and with a $17-18 \%$ increase in the likelihood of committing it after the age of 42, all other variables held constant. Early recruits committed significantly fewer crimes prior to recruitment compared to offenders recruited after the age of 26 . At the same time, the type of offense perpetrated impacts on the timing of the first mafia offense. Late recruits had a less violent, 
less serious, and more solitary pre-mafia criminal career. The average seriousness of premafia crimes has a small but significant positive impact on the likelihood of early recruitment, and a small but significant negative impact on the likelihood of late recruitment. Similarly, an increase in the share of co-offenses has a small but significant negative impact on the likelihood of late recruitment. An additional violent offense committed pre-mafia (holding constant the total number of crimes committed in this period) decreases the odds of late recruitment by approximately $6 \%$. While these last two variables (co-offending and violent crimes) have no clear impact on early recruitment separately, an additional violent offense committed in cooperation with other offenders increases by $8-11 \%$ the likelihood of being recruited before the age of 27 , and decreases by $12 \%$ the likelihood of recruitment past the age of 42 , all other variables remaining constant. Early recruits display a small but significantly lower diversity in the types of crime committed prior to recruitment $(\mathrm{OR}=0.98, \mathrm{p}<0.001)$, while the opposite holds for late recruits $(\mathrm{OR}=1.01, \mathrm{p}<0.001)$. Early recruits show a significantly higher pre-mafia escalation compared to late recruits, although the estimated effects are quite modest $(\mathrm{OR}=$ $1.002, \mathrm{p}<0.05)$. Across all models, the absence of any crime before recruitment exhibits a strong significant effect on the likelihood of early recruitment. However, it captures only $16 \%$ of the sample and $25 \%$ of the early recruits. 
Table 2. Logistic regression results for early and late recruits. Odds ratios.

\begin{tabular}{|c|c|c|c|c|c|c|c|c|}
\hline & \multicolumn{4}{|c|}{$\begin{array}{l}\text { Dependent variable: early recruit }(<27 \\
\text { years old at first mafia offense, } 20^{\text {th }} \\
\text { percentile) }\end{array}$} & \multicolumn{4}{|c|}{$\begin{array}{l}\text { Dependent variable: late recruit ( }>42 \\
\text { years old at first mafia offense, } 80^{\text {th }} \\
\text { percentile) }\end{array}$} \\
\hline & (1) & (2) & (3) & (4) & (1) & (2) & (3) & (4) \\
\hline $\begin{array}{l}\text { Pre-ma } \\
\text { dummy }\end{array}$ & $\begin{array}{l}0.0753^{* * *} \\
(0.016)\end{array}$ & $\begin{array}{l}{ }^{*} 0.0892^{* * *} \\
(0.018)\end{array}$ & $\begin{array}{l}{ }^{*} 0.0908^{* * *} \\
(0.017)\end{array}$ & $\begin{array}{l}0.0980^{* * *} \\
(0.016)\end{array}$ & $\begin{array}{l}6.394^{* * *} \\
(1.447)\end{array}$ & $\begin{array}{l}4.837^{* * *} \\
(1.057)\end{array}$ & $\begin{array}{l}3.442^{* * *} \\
(0.709)\end{array}$ & $\begin{array}{l}3.602^{* * *} \\
(0.678)\end{array}$ \\
\hline Onset age & $\begin{array}{l}0.627^{* * *} \\
(0.011)\end{array}$ & $\begin{array}{l}0.632^{* * *} \\
(0.011)\end{array}$ & $\begin{array}{l}0.631^{* * *} \\
(0.011)\end{array}$ & $\begin{array}{l}0.631^{* * *} \\
(0.010)\end{array}$ & $\begin{array}{l}1.177^{* * *} \\
(0.011)\end{array}$ & $\begin{array}{l}1.171^{* * *} \\
(0.010)\end{array}$ & $\begin{array}{l}1.166^{* * *} \\
(0.010)\end{array}$ & $\begin{array}{l}1.165^{* * *} \\
(0.009)\end{array}$ \\
\hline $\mathrm{N}$ crir & $\begin{array}{l}0.94 \\
0.0\end{array}$ & $\begin{array}{l}0.939^{* * *} \\
(0.008)\end{array}$ & $\begin{array}{l}0.930^{* * *} \\
(0.008)\end{array}$ & $\begin{array}{l}0.933^{* * *} \\
(0.007)\end{array}$ & $\begin{array}{l}1.0 \\
0.0\end{array}$ & $\begin{array}{l}1.02 \\
(0.0\end{array}$ & $\begin{array}{l}1.033^{* * *} \\
(0.006)\end{array}$ & $\begin{array}{l}1.030^{* * *} \\
(0.006)\end{array}$ \\
\hline $\begin{array}{l}\text { Diversity index pre- } \\
\text { mafia } \\
\text { Avg seriousness pre- } \\
\text { mafia }\end{array}$ & $\begin{array}{l}0.98 \\
(0.00 \\
1.00 \\
(0.00\end{array}$ & $\begin{array}{l}0.983^{* * *} \\
(0.002)\end{array}$ & $\begin{array}{l}0.984^{* * *} \\
(0.002)\end{array}$ & $\begin{array}{l}0.982^{* * *} \\
(0.002)\end{array}$ & $\begin{array}{l}1.012^{* * *} \\
(0.003) \\
0.992^{* * *} \\
(0.002)\end{array}$ & $\begin{array}{l}1.011^{* * *} \\
(0.002)\end{array}$ & $\begin{array}{l}1.009^{* * *} \\
(0.002)\end{array}$ & $\begin{array}{l}1.010^{* * *} \\
(0.002)\end{array}$ \\
\hline$\%$ co-offenses pre-mafia & $\begin{array}{l}0.998 \\
(0.002)\end{array}$ & $\begin{array}{l}1.000 \\
(0.002)\end{array}$ & & & $\begin{array}{l}0.996^{*} \\
(0.002)\end{array}$ & $\begin{array}{l}0.993^{* * *} \\
(0.002)\end{array}$ & & \\
\hline $\begin{array}{l}\mathrm{N} \text { violent offenses pre- } \\
\text { mafia }\end{array}$ & & $\begin{array}{l}1.022 \\
(0.023)\end{array}$ & & & & $\begin{array}{l}0.941^{* * *} \\
(0.017)\end{array}$ & & \\
\hline $\begin{array}{l}\mathrm{N} \text { violent co-offenses } \\
\text { pre-mafia }\end{array}$ & & & $\begin{array}{l}1.084^{* * *} \\
(0.026)\end{array}$ & $\begin{array}{l}1.107^{* * *} \\
(0.024)\end{array}$ & & & & \\
\hline Esc & $\begin{array}{l}1.002^{*} \\
(0.001)\end{array}$ & $\begin{array}{l}1.002^{* *} \\
(0.001)\end{array}$ & $\begin{array}{l}1.002^{* *} \\
(0.001)\end{array}$ & $\begin{array}{l}1.002^{* * *} \\
(0.001)\end{array}$ & $\begin{array}{l}0.999 \\
(0.001)\end{array}$ & $\begin{array}{l}0.999 \\
(0.001)\end{array}$ & $\begin{array}{l}0.999 \\
(0.001)\end{array}$ & $\begin{array}{l}0.998^{* *} \\
(0.001)\end{array}$ \\
\hline $\begin{array}{l}\text { Highe } \\
\text { dumr }\end{array}$ & $\begin{array}{l}0.588^{* * *} \\
(0.088)\end{array}$ & $\begin{array}{l}0.581^{* * *} \\
(0.086)\end{array}$ & $\begin{array}{l}0.579 * * * \\
(0.086)\end{array}$ & & $\begin{array}{l}1.005 \\
(0.140)\end{array}$ & $\begin{array}{l}1.026 \\
(0.141)\end{array}$ & $\begin{array}{l}1.013 \\
(0.139)\end{array}$ & \\
\hline Year & $\begin{array}{l}1.238^{* * *} \\
(0.009)\end{array}$ & $\begin{array}{l}1.237^{* * *} \\
(0.009)\end{array}$ & $\begin{array}{l}1.236^{* * *} \\
(0.009)\end{array}$ & $\begin{array}{l}1.216^{* * *} \\
(0.008)\end{array}$ & $\begin{array}{l}0.772^{* * *} \\
(0.006)\end{array}$ & $\begin{array}{l}0.773^{* * *} \\
(0.006)\end{array}$ & $\begin{array}{l}0.769^{* * *} \\
(0.006)\end{array}$ & $\begin{array}{l}0.770^{* * *} \\
(0.006)\end{array}$ \\
\hline Col & $\begin{array}{l}17.23^{* * *} \\
(9.273)\end{array}$ & $\begin{array}{l}14.68^{* * *} \\
(7.802)\end{array}$ & $\begin{array}{l}15.11^{* * *} \\
(8.020)\end{array}$ & $\begin{array}{l}26.56^{* * *} \\
(12.657)\end{array}$ & $\begin{array}{l}3.258^{*} \\
(1.541)\end{array}$ & $\begin{array}{l}3.852^{* *} \\
(1.791)\end{array}$ & $\begin{array}{l}5.449^{* * *} \\
(2.494)\end{array}$ & $\begin{array}{l}5.403^{* * *} \\
(2.259)\end{array}$ \\
\hline & 0.54 & 0.54 & 0.54 & 0.53 & 0.58 & 0.58 & 0.58 & 0.58 \\
\hline Observations & 7,412 & 7,488 & 7,488 & 9,070 & 7,412 & 7,488 & 7,488 & 9,070 \\
\hline
\end{tabular}

Notes: standard errors reported in parenthesis. ${ }^{*}{ }^{* *}$ and ${ }^{* * *}$ indicate statistical significance at the 5,1 and 0.1 per cent level, respectively.

All the results are confirmed in the model excluding the education variable (column 4 of Table 2), thus ruling out the possibility that they were affected by the presence of missing values. At the same time, early recruited offenders were $41-42 \%$ less likely to have completed high school compared to offenders who joined the mafia organization after the age of 26. This is an intuitive result considering the earlier onset of early recruits, which happens on average in their late teenage years. Conversely, completing high school does not impact on differences in the timing of recruitment after the age of 26.

\section{Robustness checks}

We tested the robustness of the results by means of various additional models. First, to ensure that the results were not driven by generational differences between early and late recruits (the latter born on average in older calendar years compared to the former), we ran the same specifications on a subsample of offenders born between 1962 and 1970 (Table 3), with results that confirmed those presented in Table 2. The coefficients for the pre-mafia career dummy are even greater in this subsample, and the same holds for other characteristics - namely, the diversity index, the average seriousness, the share of co- 
offenses, and the number of violent offenses and violent co-offenses. Second, Table 4 presents results for a sample including only offenders with at least two offenses prior to recruitment, and for models where the thresholds identifying early and late recruits were shifted to the $15^{\text {th }}$ and $25^{\text {th }}$ percentile (early), and the $85^{\text {th }}$ and $75^{\text {th }}$ percentile (late), respectively. Again, the results were essentially unchanged in terms of significance and direction, and very similar in terms of magnitude to those in Table 2, column 3.

Table 3. Logistic regression results for early and late recruits, restricted sample of offenders born in 1962-1970. Odds ratios.

\begin{tabular}{|c|c|c|c|c|c|c|c|c|}
\hline & \multicolumn{4}{|c|}{$\begin{array}{c}\text { Dependent variable: early recruit }(<27 \\
\text { years old at first mafia offense, } 20^{\text {th }} \\
\text { percentile) }\end{array}$} & \multicolumn{4}{|c|}{$\begin{array}{l}\text { Dependent variable: late recruit ( }>42 \text { years } \\
\text { old at first mafia offense, } 80^{\text {th }} \text { percentile) }\end{array}$} \\
\hline & (1) & (2) & (3) & (4) & (1) & (2) & (3) & (4) \\
\hline $\begin{array}{l}\text { Pre-mafia career } \\
\text { dummy }\end{array}$ & $\begin{array}{l}0783^{* * *} \\
024)\end{array}$ & $\begin{array}{l}0.0981^{* * *} \\
(0.029)\end{array}$ & $\begin{array}{l}0.107^{* * *} \\
(0.029)\end{array}$ & $\begin{array}{l}0.102^{* * *} \\
(0.026)\end{array}$ & $\begin{array}{l}8.210^{* * *} \\
(3.003)\end{array}$ & $\begin{array}{l}5.065^{* * *} \\
(1.780)\end{array}$ & $\begin{array}{l}3.309 * * * \\
(1.072)\end{array}$ & $\begin{array}{l}4.401^{* * *} \\
(1.330)\end{array}$ \\
\hline Onset age & $\begin{array}{l}0.672^{* * *} \\
(0.017)\end{array}$ & $\begin{array}{l}0.678^{* * *} \\
(0.017)\end{array}$ & $\begin{array}{l}0.677^{* * *} \\
(0.017)\end{array}$ & $\begin{array}{l}0.678^{* * *} \\
(0.015)\end{array}$ & $\begin{array}{l}1.243^{* * *} \\
(0.023)\end{array}$ & $\begin{array}{l}1.237^{* * *} \\
(0.022)\end{array}$ & $\begin{array}{l}1.232^{* * *} \\
(0.022)\end{array}$ & $\begin{array}{l}1.233^{* * *} \\
(0.020)\end{array}$ \\
\hline $\mathrm{N}$ crimes pre-mafia & $\begin{array}{l}0.954^{* * *} \\
(0.009)\end{array}$ & $\begin{array}{l}0.948^{* * *} \\
(0.011)\end{array}$ & $\begin{array}{l}0.938^{* * *} \\
(0.011)\end{array}$ & $\begin{array}{l}0.942^{* * *} \\
(0.010)\end{array}$ & $\begin{array}{l}1.021^{*} \\
(0.010)\end{array}$ & $\begin{array}{l}1.041^{* *} \\
(0.013)\end{array}$ & $\begin{array}{l}1.041^{* * *} \\
(0.012)\end{array}$ & $\begin{array}{l}1.045^{* * *} \\
(0.011)\end{array}$ \\
\hline $\begin{array}{l}\text { Diversity index pre- } \\
\text { mafia }\end{array}$ & $\begin{array}{l}0.979 * * * \\
(0.003)\end{array}$ & $\begin{array}{l}0.980^{* * *} \\
(0.003)\end{array}$ & $\begin{array}{l}0.980^{* * *} \\
(0.003)\end{array}$ & $\begin{array}{l}0.980^{* * *} \\
(0.003)\end{array}$ & $\begin{array}{l}1.013^{* *} \\
(0.005)\end{array}$ & $\begin{array}{l}1.011^{*} \\
(0.004)\end{array}$ & $\begin{array}{l}1.011^{*} \\
(0.004)\end{array}$ & $\begin{array}{l}1.010^{*} \\
(0.004)\end{array}$ \\
\hline $\begin{array}{l}\text { Avg. seriousness pre- } \\
\text { mafia }\end{array}$ & $\begin{array}{l}1.007^{* * *} \\
(0.002)\end{array}$ & & & & $\begin{array}{l}0.984^{* * *} \\
(0.004)\end{array}$ & & & \\
\hline $\begin{array}{l}\% \text { co-offenses pre- } \\
\text { mafia } \\
\mathrm{N} \text { violent offenses pre- } \\
\text { mafia }\end{array}$ & $\begin{array}{l}0.999 \\
(0.002)\end{array}$ & $\begin{array}{l}1.002 \\
(0.002) \\
1.034 \\
(0.031)\end{array}$ & & & $\begin{array}{l}0.997 \\
(0.004)\end{array}$ & $\begin{array}{l}0.992^{*} \\
(0.003) \\
0.888^{*} \\
(0.043)\end{array}$ & & \\
\hline $\begin{array}{l}\mathrm{N} \text { violent co-offenses } \\
\text { pre-mafia }\end{array}$ & & & $\begin{array}{l}1.110^{* *} \\
(0.036)\end{array}$ & $\begin{array}{l}1.144^{* * *} \\
(0.034)\end{array}$ & & & $\begin{array}{l}0.765^{* * *} \\
(0.061)\end{array}$ & $\begin{array}{l}0.741^{* * *} \\
(0.055)\end{array}$ \\
\hline Escalation pre-mafia & $\begin{array}{l}1.002^{*} \\
(0.001)\end{array}$ & $\begin{array}{l}1.003^{*} \\
(0.001)\end{array}$ & $\begin{array}{l}1.003^{*} \\
(0.001)\end{array}$ & $\begin{array}{l}1.003^{* *} \\
(0.001)\end{array}$ & $\begin{array}{l}0.995^{*} \\
(0.002)\end{array}$ & $\begin{array}{l}0.997 \\
(0.002)\end{array}$ & $\begin{array}{l}0.997 \\
(0.002)\end{array}$ & $\begin{array}{l}0.997 \\
(0.002)\end{array}$ \\
\hline $\begin{array}{l}\text { Higher education } \\
\text { dummy }\end{array}$ & $\begin{array}{l}0.617^{*} \\
(0.142)\end{array}$ & $\begin{array}{l}0.591^{*} \\
(0.135)\end{array}$ & $\begin{array}{l}0.584^{*} \\
(0.133)\end{array}$ & & $\begin{array}{l}1.177 \\
(0.301)\end{array}$ & $\begin{array}{l}1.165 \\
(0.297)\end{array}$ & $\begin{array}{l}1.074 \\
(0.274)\end{array}$ & \\
\hline Year of birth scaled & $\begin{array}{l}1.350^{* * *} \\
(0.036)\end{array}$ & $\begin{array}{l}1.353^{* * *} \\
(0.036)\end{array}$ & $\begin{array}{l}1.351^{* * *} \\
(0.036)\end{array}$ & $\begin{array}{l}1.325^{* * *} \\
(0.032)\end{array}$ & $\begin{array}{l}0.718^{* * *} \\
(0.032)\end{array}$ & $\begin{array}{l}0.725^{* * *} \\
(0.031)\end{array}$ & $\begin{array}{l}0.720^{* * *} \\
(0.031)\end{array}$ & $\begin{array}{l}0.717^{* * *} \\
(0.028)\end{array}$ \\
\hline Cons & $\begin{array}{l}0.161 \\
(0.195)\end{array}$ & $\begin{array}{l}0.117 \\
(0.141)\end{array}$ & $\begin{array}{l}0.131 \\
(0.158)\end{array}$ & $\begin{array}{l}0.256 \\
(0.282)\end{array}$ & $\begin{array}{l}17.41 \\
(31.742)\end{array}$ & $\begin{array}{l}15.00 \\
(27.127)\end{array}$ & $\begin{array}{l}23.51 \\
(42.188)\end{array}$ & $\begin{array}{l}22.10 \\
(36.141)\end{array}$ \\
\hline & 0.29 & 0.29 & 0.29 & 0.29 & 0.29 & 0.28 & 0.27 & 0.27 \\
\hline Observations & 2,471 & 2,496 & 2,496 & 2,970 & 2,471 & 2,496 & 2,496 & 2,970 \\
\hline
\end{tabular}

Notes: standard errors reported in parenthesis. ${ }^{*}{ }^{* *}$ and ${ }^{* * *}$ indicate statistical significance at the 5,1 and 0.1 per cent level, respectively. 
Table 4. Logistic regression results, only offenders with at least two offenses prior mafia offense, and change in percentile thresholds, for early/late recruits. Odds ratios.

\begin{tabular}{|c|c|c|c|c|c|c|}
\hline & \multicolumn{3}{|c|}{ Dependent variable: early recruit } & \multicolumn{3}{|c|}{ Dependent variable: late recruit } \\
\hline & $\begin{array}{l}\text { At least two } \\
\text { offenses } \\
\text { pre-mafia }\end{array}$ & $\begin{array}{c}\text { (<25 years } \\
\text { old at first } \\
\text { mafia } \\
\text { offense, } \\
15^{\text {th }} \\
\text { percentile) }\end{array}$ & $\begin{array}{c}\text { (<28 years } \\
\text { old at first } \\
\text { mafia } \\
\text { offense, } \\
25^{\text {th }} \\
\text { percentile) }\end{array}$ & $\begin{array}{l}\text { At least two } \\
\text { offenses } \\
\text { pre-mafia }\end{array}$ & $\begin{array}{c}\text { (>46 years } \\
\text { old at first } \\
\text { mafia } \\
\text { offense, } \\
\text { 85 } \\
\text { percentile) }\end{array}$ & $\begin{array}{c}\text { (>40 years } \\
\text { old at first } \\
\text { mafia } \\
\text { offense, } \\
75^{\text {th }} \\
\text { percentile) }\end{array}$ \\
\hline Pre-mafia career dummy & & $\begin{array}{c}0.0685^{* * *} \\
(0.014)\end{array}$ & $\begin{array}{l}0.121^{* * *} \\
(0.021)\end{array}$ & & $\begin{array}{l}1.863^{* *} \\
(0.430)\end{array}$ & $\begin{array}{l}4.120^{* * *} \\
(0.797)\end{array}$ \\
\hline Onset age & $\begin{array}{l}0.699 * * * \\
(0.014)\end{array}$ & $\begin{array}{l}0.561^{* * *} \\
(0.013)\end{array}$ & $\begin{array}{l}0.669 * * * \\
(0.010)\end{array}$ & $\begin{array}{l}1.119^{* * *} \\
(0.011)\end{array}$ & $\begin{array}{l}1.123^{* * *} \\
(0.010)\end{array}$ & $\begin{array}{l}1.181^{* * *} \\
(0.010)\end{array}$ \\
\hline $\mathrm{N}$ crimes pre-mafia & $\begin{array}{l}0.941^{* * *} \\
(0.008)\end{array}$ & $\begin{array}{l}0.908^{* * *} \\
(0.009)\end{array}$ & $\begin{array}{l}0.931^{* * *} \\
(0.007)\end{array}$ & $\begin{array}{l}1.026^{* * *} \\
(0.006)\end{array}$ & $\begin{array}{l}1.020^{* *} \\
(0.007)\end{array}$ & $\begin{array}{l}1.035^{* * *} \\
(0.006)\end{array}$ \\
\hline Diversity index pre-mafia & $\begin{array}{l}0.988^{* * *} \\
(0.003)\end{array}$ & $\begin{array}{l}0.985^{* * *} \\
(0.002)\end{array}$ & $\begin{array}{c}0.985^{* * *} \\
(0.002)\end{array}$ & $\begin{array}{l}1.008^{*} \\
(0.004)\end{array}$ & $\begin{array}{l}1.013^{* * *} \\
(0.003)\end{array}$ & $\begin{array}{l}1.011^{* * *} \\
(0.002)\end{array}$ \\
\hline $\begin{array}{l}\mathrm{N} \text { violent co-offenses pre- } \\
\text { mafia }\end{array}$ & $\begin{array}{l}1.076^{* *} \\
(0.026)\end{array}$ & $\begin{array}{l}1.096^{* *} \\
(0.035)\end{array}$ & $\begin{array}{l}1.103^{* * *} \\
(0.025)\end{array}$ & $\begin{array}{l}0.891^{* * *} \\
(0.020)\end{array}$ & $\begin{array}{l}0.901^{* * *} \\
(0.025)\end{array}$ & $\begin{array}{l}0.874^{* * *} \\
(0.017)\end{array}$ \\
\hline Escalation pre-mafia & $\begin{array}{l}1.002^{*} \\
(0.001)\end{array}$ & $\begin{array}{l}1.002^{*} \\
(0.001)\end{array}$ & $\begin{array}{l}1.002^{* *} \\
(0.001)\end{array}$ & $\begin{array}{c}0.999 \\
(0.001)\end{array}$ & $\begin{array}{c}0.998 \\
(0.001)\end{array}$ & $\begin{array}{c}0.999 \\
(0.001)\end{array}$ \\
\hline Higher education dummy & $\begin{array}{l}0.666^{*} \\
(0.127)\end{array}$ & $\begin{array}{l}0.692^{*} \\
(0.120)\end{array}$ & $\begin{array}{l}0.622^{* * *} \\
(0.086)\end{array}$ & $\begin{array}{c}1.078 \\
(0.177)\end{array}$ & $\begin{array}{c}0.955 \\
(0.153)\end{array}$ & $\begin{array}{c}1.189 \\
(0.149)\end{array}$ \\
\hline Year of birth scaled & $\begin{array}{l}1.255^{* * *} \\
(0.011)\end{array}$ & $\begin{array}{l}1.201^{* * *} \\
(0.010)\end{array}$ & $\begin{array}{l}1.231^{* * *} \\
(0.008)\end{array}$ & $\begin{array}{c}0.757^{* * *} \\
(0.007)\end{array}$ & $\begin{array}{l}0.761^{* * *} \\
(0.007)\end{array}$ & $\begin{array}{l}0.778^{* * *} \\
(0.006)\end{array}$ \\
\hline Constant & $\begin{array}{l}0.0685^{* * *} \\
(0.038)\end{array}$ & $\begin{array}{c}240.4^{* * *} \\
(153.623)\end{array}$ & $\begin{array}{l}6.350^{* * *} \\
(3.089)\end{array}$ & $\begin{array}{l}87.54^{* * *} \\
(43.238)\end{array}$ & $\begin{array}{l}7.904^{* * *} \\
(4.008)\end{array}$ & $\begin{array}{l}4.172^{* * *} \\
(1.798)\end{array}$ \\
\hline $\begin{array}{l}\text { Pseudo R2 } \\
\text { Observations }\end{array}$ & $\begin{array}{c}0.44 \\
5,524\end{array}$ & $\begin{array}{c}0.55 \\
7,488\end{array}$ & $\begin{array}{c}0.52 \\
7,488\end{array}$ & $\begin{array}{c}0.54 \\
5,524\end{array}$ & $\begin{array}{c}0.60 \\
7,488\end{array}$ & $\begin{array}{c}0.56 \\
7,488\end{array}$ \\
\hline
\end{tabular}

Notes: standard errors reported in parenthesis. ${ }^{*},{ }^{* *}$ and ${ }^{* * *}$ indicate statistical significance at the 5,1 and 0.1 per cent level, respective.

\section{Discussion and conclusions}

\section{Research questions and main findings}

Scholars have paid limited attention to recruitment into organized crime, primarily for reasons of data availability. Most importantly, studies concerned with understanding the factors leading to recruitment often assume the existence of a homogenous pathway into organized crime and overlook the differences among offenders recruited at different ages. This study has addressed this gap in research by assessing whether offenders recruited at an early as opposed to a late age present significant differences in their criminal careers prior to recruitment (research question 1), and by examining the nature of these differences (research question 2).

Our results show significantly different criminal pathways into organized crime for individuals recruited at different ages. Previous research has already identified multiple factors favoring organized crime recruitment, but it has failed to explore how different factors are correlated with involvement in organized crime at distinct ages. Our results are 
generally consistent with research suggesting that early onset may lead to serious offending, and that certain social relations and criminal skills favor the involvement in organized crime at a younger age (Comunale et al., 2020; Gambetta, 1993; Paoli, 2003). In particular, engaging in violent co-offending facilitates early recruitment, suggesting that early recruits are often embedded in a violent context even before their formal admission to the mafia (Paoli, 2003). In this context, violent co-offending in the criminal career prior to mafia affiliation reveals the preliminary steps of the involvement in the criminal group's activities, possibly prompted by mechanisms of social learning and differential association with kinship and social ties (Albini, 1971). Committing violent crimes in the presence of cooffenders can be also interpreted as a signal of trustworthiness and of the will to join a mafia (Gambetta, 2009; Pyrooz \& Densley, 2016). Engaging in violent crimes is a means to prove one's credibility, which has specific importance in the context of organized crime compared to when considering criminal cooperation for other types of offenders. Joining a mafia group requires a strong commitment considering both the profound personal involvement and the high risks that offenders face in the case of arrest (in terms of heavy penalties or risk of retaliation if they decide to cooperate with law enforcement). In this last respect, the higher average seriousness characterizing early recruits' pre-mafia career can also be read as a credibility signal - the greater the crime seriousness, the more severe the sanction (Campana \& Varese, 2013). Overall, the criminal behavior of early recruits is aligned with the characteristics of offenders identified as 'life-course persistent' or 'serious' offenders, who report an early onset, a high frequency, and are responsible for the most serious and violent offenses (Loeber \& Ahonen, 2014; Moffitt, 1993). However, while Moffitt's (1993) theory posits that life-course persistent offenders are willing to solo offend due to their strong internal motivation towards delinquency, our results show that early starters may frequently engage in violent co-offending prior to their organized crime recruitment.

Early recruitment is also correlated with lower odds of high school graduation, while higher education does not impact on recruitment at later stages. The results are even more interesting given that early recruits were born more recently (on average in 1975), during periods when high school completion rates in Italy were considerably higher than in previous decades. While only $10 \%$ of early recruits completed high school, nationwide completion rates were approximately $50 \%$ in the 1970 s and 1980 s and exceeded $60 \%$ in the 1990s (Istat, 2020). The disproportion between mafia offenders and the general population suggests that early recruits are a minority of disadvantaged individuals with social, economic, and cultural features that may aggravate the embeddedness in crimeprone environments and the criminal background.

Offenders recruited at later ages follow different recruitment pathways, with a much longer 'incubation' period before joining the mafia group compared to that of early recruits. The findings indicate that these offenders may not resort to strategic behavior to signal their interest to join the mafia group. Late onset has often been linked with the social embeddedness and social opportunity structure theories of involvement in organized crime (Kleemans \& De Poot, 2008; Kleemans \& Van de Bunt, 1999). These theories posit that individuals become involved in organized crime because of specific personal skills, social relations, or work-related opportunities (Van Koppen \& De Poot, 2013). Mafia 
groups may be interested in these offenders because they have some specific expertise and criminal and non-criminal skills that are developed only at later ages. However, contrary to our hypothesis, we found that a higher diversity index increases the likelihood of being a late recruit. These offenders are more versatile than specialized, although the higher diversity score may be due to the larger number of crimes committed over a longer premafia career. Our findings thus do not support the idea that specific expertise in certain crime types drives late recruitment. Nevertheless, late recruits may attract the interest of mafia groups owing to their professional rather than criminal expertise. The PMM data set provides some support for this interpretation, since it shows a higher proportion of managers, employees, and entrepreneurs among late recruits, and a higher proportion of workmen among early recruits (Table 5). However, information on the occupation was missing for 51 percent of the sample (consequently, we opted not to include it in the models) and may simply reflect the fact that early recruits were arrested at a younger age and thus could not progress in their professional careers. Future research may develop further insights into the non-criminal characteristics of late recruits.

Table 5. Distribution of profession at first arrest, whole sample and by recruitment age.

\begin{tabular}{lccc}
\hline Profession at first arrest & $\begin{array}{c}\text { Whole } \\
\text { sample } \\
(\%)\end{array}$ & $\begin{array}{c}\text { Early mafia involvement } \\
(\%)\end{array}$ & $\begin{array}{c}\text { Late mafia involvement } \\
(\%)\end{array}$ \\
\hline Director/manager & 2.47 & 1.06 & 3.38 \\
Employee & 7.31 & 7.05 & 9.73 \\
Entrepreneur & 8.96 & 6.37 & 13.96 \\
Freelance & 6.24 & 4.54 & 6.01 \\
Other & 2.65 & 2.61 & 3.05 \\
Self-employed & 15.38 & 12.55 & 15.14 \\
Workman/head- & 56.99 & 65.83 & 48.73 \\
workman & & & 1,182 \\
$\mathrm{~N}$ & 5,434 & 1,036 & \\
\hline
\end{tabular}

\section{Limitations}

In addition to the methodological issues discussed in the previous sections, we acknowledge that our analysis has other significant limitations. First, although the literature emphasizes the importance of social relations for recruitment into organized crime, our data lacked information on, for example, kinship. Data protection and full anonymization prevented any identification of the offenders and integration with additional socio-demographic information. Second, we relied on official conviction data, which certainly underestimate offending levels. The issue is common to a large amount of research in this field, although it was partially mitigated by the large size of our sample which enabled us to focus on differences among different types of offenders rather than on the absolute count of their crimes. In this regard, we assumed that there were no systematic errors of measurement between the official convictions of early and late offenders other than the above-discussed generational bias. 


\section{Recommendations for policy and future research}

The results of this study have important implications in terms of policy. Primarily, they show that prevention policies intended to curb processes of recruitment into criminal groups cannot be homogenous. Because early recruits tend to have a lower education, coupled with a short and violent criminal career prior to recruitment, the first set of prevention policies should target youths living in mafia-prone environments, and they should be based on initiatives of community-level and school-level socialization, as suggested also by Calderoni and colleagues (2021), who used agent-based models to test the effect of different policies. The goal of these instruments would be twofold: first, by increasing the amount of time spent in school or recreational centers, they would seek to decrease opportunities for socialization into criminal skills outside school; second, they would aim to provide youths with notions and skills functional to a career in the lawful world. Policy responses targeting offenders of this type may be onerous, but they are especially important to offer a valid alternative to individuals at high risk of persistent delinquency. The second set of prevention policies should instead target individuals in their middle adulthood and consist of instruments inducing skilled individuals to engage in legitimate activities by making illegitimate ones less attractive. This type of policy could include severe sanctions for organized crime-related offenses, as well as tight control procedures in those work environments that are highly attractive for mafia groups (e.g., ports, airports, customs).

Future research could build on our results. In particular, it might be appropriate to explore various measures of specialization, types of offenses, and offending mix in order to verify whether some specific patterns differentiate early and late recruits. Furthermore, it might be interesting to replicate the analysis and investigate whether the differences are confirmed in other organized crime populations or across different types of mafias. Lastly, examinations of offending careers after recruitment might furnish insights into the impact of mafia membership at different ages on the criminal career's trajectory.

\section{Conclusions}

Relying on the largest sample of organized crime offenders so far analyzed in the literature, our analysis examined the factors leading to early and late recruitment into Italian organized crime. Our findings indicate different pathways: early recruits show an earlier onset, with less prolific, less versatile, and more serious offending; late recruits record a later onset, with more prolific and versatile - but less serious - offending. Furthermore, violent co-offending increases the probability of early recruitment while it decreases the likelihood of late recruitment. The results are robust to different subsamples and thresholds for the identification of early/late recruits. Overall, the findings suggest that recruitment into organized crime is not a uniform process, and that the different timings of involvement can furnish insights into the characteristics of the offenders. Young recruits appear to be embedded in a criminal and violent context even before their formal recruitment, and they may engage in serious and violent co-offending to signal their commitment to joining the criminal group (Gambetta, 2009; Paoli, 2003). In this context, school or community initiatives that offer attractive recreational activities to children and adolescents may be valuable policy instruments with which to prevent organized crime 
recruitment. Late recruits have instead more prolonged but significantly less serious criminal careers prior to their organized crime involvement, which might be driven by specific professional skills or opportunities arising later in life (Kleemans \& De Poot, 2008; Van Koppen \& De Poot, 2013). Future research should gather additional social and contextual information to identify specific work environments and occupations that are highly attractive for organized criminal groups, thus making it possible to design a system of targeted sanctions and control procedures.

\section{References}

Albini, J. L. (1971). The American Mafia: Genesis of a legend. Appleton-Century-Crofts. Arlacchi, P. (1983). La mafia imprenditrice. Il Mulino.

Arlacchi, P. (1994). Addio Cosa Nostra. La vita di Tommaso Buscetta (1st ed.). Rizzoli. Behan, T. (1996). The Camorra. Routledge.

Blok, A. (1975). The Mafia of a Sicilian village, 1860 - 1960: A study of violent peasant entrepreneurs. Harper \& Row.

Blokland, A., Van Hout, L., Van der Leest, W., \& Soudijn, M. (2019). Not your average biker; criminal careers of members of Dutch outlaw motorcycle gangs. Trends in Organized Crime, 22(1), 10-33. https://doi.org/10.1007/s12117-017-9303-x

Blumstein, A., Cohen, J., Roth, J. A., \& Visher, C. A. (1986). Criminal careers and "career criminals" (National Research Council (U.S.) Panel on Research on Criminal Careers). National Academy Press.

Brancaccio, L. (2017). I clan di camorra: Genesi e storia. Donzelli editore.

Calderoni, F., Campedelli, G. M., Szekely, A., Paolucci, M., \& Andrighetto, G. (2021).

Recruitment into Organized Crime: An Agent-Based Approach Testing the Impact of Different Policies. Journal of Quantitative Criminology. https://doi.org/10.1007/s10940020-09489-z

Campana, P., \& Varese, F. (2013). Cooperation in criminal organizations: Kinship and violence as credible commitments. Rationality and Society, 25(3), 263-289. https://doi.org/10.1177/1043463113481202

Campedelli, G. M., Calderoni, F., Comunale, T., \& Meneghini, C. (2019). Life-Course Criminal Trajectories of Mafia Members. Crime \& Delinquency.

https://doi.org/10.1177/0011128719860834

Catino, M. (2019). Mafia Organizations: The visible hand of criminal enterprise. Cambridge University Press.

Catino, M. (2020). Italian Organized Crime since 1950. Crime and Justice, 49, 69-140. https://doi.org/10.1086/707319 
Ciconte, E. (1992). 'Ndrangheta dall'Unità a oggi. Laterza.

Comunale, T., Calderoni, F., Marchesi, M., Superchi, E., \& Campedelli, G. M. (2020). Systematic Review of the Social, Psychological and Economic Factors Relating to Involvement and Recruitment into Organized Crime. In D. Weisburd, E. U. Savona, B. Hasisi, \& F. Calderoni (Eds.), Understanding Recruitment to Organized Crime and Terrorism (pp. 175-204). Springer International Publishing. https://doi.org/10.1007/978-3-030-36639$1+8$

Conway, K. P., \& McCord, J. (2002). A longitudinal examination of the relation between cooffending with violent accomplices and violent crime. Aggressive Behavior, 28(2), 97-108.

Cressey, D. R. (1969). Theft of the Nation: The Structure and Operations of Organized Crime in America. Harper and Row.

Decker, S. H., \& Pyrooz, D. C. (2014). Gangs: Another form of organized crime. In L. Paoli (Ed.), The Oxford Handbook of Organized Crime (pp. 270-287). Oxford University Press.

Densley, J. (2013). How Gangs Work: An Ethnography of Youth Violence. Palgrave Macmillan UK.

Desmond, E., \& Hussain, N. (2017). Organized Crime and Terrorism. In J. D. Freilich \& G. LaFree (Eds.), The handbook of the criminology of terrorism (pp. 373-384). Wiley Blackwell.

Eggleston, E. P., \& Laub, J. H. (2002). The onset of adult offending: A neglected dimension of the criminal career. Journal of Criminal Justice, 30(6), 603-622.

https://doi.org/10.1016/S0047-2352(02)00193-9

Farrington, D. P., Ttofi, M. M., Crago, R. V., \& Coid, J. W. (2014). Prevalence, frequency, onset, desistance and criminal career duration in self-reports compared with official records: Onset, desistance and criminal career duration. Criminal Behaviour and Mental Health, 24(4), 241-253. https://doi.org/10.1002/cbm.1930

Francis, B., Humphreys, L., Kirby, S., \& Soothill, K. (2013). Understanding Criminal Careers in Organised Crime. Research Report 74. Home Office.

Gambetta, D. (1993). The Sicilian Mafia: The Business of Private Protection. Harvard University Press.

Gambetta, D. (2009). Codes of the underworld: How criminals communicate. Princeton Univ. Press.

Gambetta, D. (2011). Signaling. In P. Bearman \& P. Hedström (Eds.), The Oxford Handbook of Analytical Sociology. Oxford University Press.

https://doi.org/10.1093/oxfordhb/9780199215362.013.8

Hagan, F. (2006). "Organized crime" and "organized crime": Indeterminate problems of definition. Trends in Organized Crime, 9(4), 127-137.

Hess, H. (1993). Mafia: Le origini e la struttura. Laterza. 
Higginson, A., Benier, K., Shenderovich, Y., Bedford, L., Mazerolle, L., \& Murray, J. (2015). Preventive Interventions to Reduce Youth Involvement in Gangs and Gang Crime in Lowand Middle-Income Countries: A Systematic Review. Campbell Systematic Reviews, 18. https://doi.org/10.4073/csr.2015.18

Higginson, A., Benier, K., Shenderovich, Y., Bedford, L., Mazerolle, L., \& Murray, J. (2018). Factors associated with youth gang membership in low- and middle- income countries: A systematic review. Campbell Systematic Reviews, 11. https://doi.org/10.4073/csr.2018.11

Hobbs, D., \& Antonopoulos, G. A. (2014). How to Research Organized Crime. In L. Paoli (Ed.), The Oxford Handbook of Organized Crime (pp. 96-117). Oxford University Press.

Hodgkinson, J., Marshall, S., Berry, G., Newman, M., Reynolds, P., Burton, E., Dickson, K., \& Anderson, J. (2009). Reducing gang related crime: A systematic review of "comprehensive" interventions. Technical report. In Research Evidence in Education Library. EPPI-Centre, Social Science Research Unit, Institute of Education, University of London.

Ianni, F. A., \& Reuss-Ianni, E. (1972). A family business: Kinship and social control in organized crime. Russell Sage Foundation.

Istat. (2020). Tavola 7.12 -Tasso di conseguimento del titolo di studio per livello di istruzione e sesso-Anni scolastici 1949/50-2013/14. Serie Storiche.

http://seriestoriche.istat.it/fileadmin/documenti/Tavola_7.12.xls

Kemp, L., Zolghadriha, S., \& Gill, P. (2019). Pathways into organized crime: Comparing founders and joiners. Trends in Organized Crime. https://doi.org/10.1007/s12117-01909371-w

Kirby, S., Francis, B., Humphreys, L., \& Soothill, K. (2016). Using the UK general offender database as a means to measure and analyse organized crime. Policing: An International Journal of Police Strategies \& Management, 39(1), 78-94. https://doi.org/10.1108/PIJPSM03-2015-0024

Kleemans, E. R., \& De Poot, C. J. (2008). Criminal Careers in Organized Crime and Social Opportunity Structure. European Journal of Criminology, 5(1), 69-98.

https://doi.org/10.1177/1477370807084225

Kleemans, E. R., \& Van de Bunt, H. (1999). The social embeddedness of organized crime. Transnational Organized Crime, 5(1), 19-36.

Kleemans, E. R., \& Van Koppen, M. V. (2014). Careers in organized crime. In D. Weisburd \& G. Bruinsma (Eds.), Encyclopedia of Criminology and Criminal Justice (pp. 285-295). Springer.

Kleemans, E. R., \& Van Koppen, M. V. (2020). Organized Crime and Criminal Careers. Crime and Justice. https://doi.org/10.1086/707318

Klein, M. W., \& Maxson. (2006). Street gang patterns and policies. Oxford University Press. 
Klement, C. (2016a). Outlaw biker affiliations and criminal involvement. European Journal of Criminology, 13(4), 453-472. https://doi.org/10.1177/1477370815626460

Klement, C. (2016b). Crime prevalence and frequency among Danish outlaw bikers. Journal of Scandinavian Studies in Criminology and Crime Prevention, 17(2), 131-149. https://doi.org/10.1080/14043858.2016.1240420

La Spina, A. (2004). The Paradox of Effectiveness: Growth, Institutionalisation and Evaluation of Anti-Mafia Policies in Italy. In C. Fijnaut \& L. Paoli (Eds.), Organised Crime in Europe: Concepts, Patterns and Control Policies in the European Union and Beyond (pp. 641675). Springer Netherlands. https://doi.org/10.1007/978-1-4020-2765-9_24

La Spina, A. (2014). The Fight Against the Italian Mafia. In L. Paoli (Ed.), The Oxford Handbook of Organized Crime (pp. 593-611). Oxford University Press. http://www.oxfordhandbooks.com/view/10.1093/oxfordhb/9780199730445.001.0001/ oxfordhb-9780199730445-e-005

Lantz, B. (2019). Co-offending Group Composition and Violence: The Impact of Sex, Age, and Group Size on Co-offending Violence. Crime \& Delinquency. https://doi.org/10.1177/0011128719834564

Lantz, B., \& Kim, J. (2019). Hate Crimes Hurt More, but so Do Co-Offenders: Separating the Influence of Co-Offending and Bias on Hate-Motivated Physical Injury. Criminal Justice and Behavior, 46(3), 437-456. https://doi.org/10.1177/0093854818810314

Liu, J., Francis, B., \& Soothill, K. (2011). A Longitudinal Study of Escalation in Crime Seriousness. Journal of Quantitative Criminology, 27(2), 175-196. https://doi.org/10.1007/s10940-010-9102-x

Loeber, R., \& Ahonen, L. (2014). What are the Policy Implications of Our Knowledge on Serious, Violent, and Chronic Offenders? Criminology \& Public Policy, 13(1), 117-125. https://doi.org/10.1111/1745-9133.12072

Loeber, R., Farrington, D. P., \& Petechuk, D. (2003). Child Delinquency: Early Intervention and Prevention. Washington, DC: Office of Justice Programs, Office of Juvenile Justice and Delinquency Prevention, U.S. Department of Justice.

Maltz, M. D. (1976). On Defining "Organized Crime": The Development of a Definition and a Typology. Crime \& Delinquency, 338-346. https://doi.org/10.1177/001112877602200306

McCord, J., \& Conway, K. P. (2002). Patterns of juvenile delinquency and co-offending. Crime and Social Organization, 10, 15-30.

McGilloway, A., Ghosh, P., \& Bhui, K. (2015). A systematic review of pathways to and processes associated with radicalization and extremism amongst Muslims in Western societies. International Review of Psychiatry, 27(1), 39-50.

https://doi.org/10.3109/09540261.2014.992008 
McGloin, J. M., \& Piquero, A. R. (2009). 'I Wasn't Alone': Collective Behaviour and Violent Delinquency. Australian \& New Zealand Journal of Criminology, 42(3), 336-353.

https://doi.org/10.1375/acri.42.3.336

Melde, C., \& Esbensen, F.-A. (2011). Gang Membership as a Turning Point in the Life Course. Criminology, 49(2), 513-552. https://doi.org/10.1111/j.1745-9125.2011.00227.x

Moffitt, T. E. (1993). Adolescence-limited and life-course-persistent antisocial behavior: A developmental taxonomy. Psychological Review, 100(4), 674-701.

Morgan, A., Brown, R., \& Fuller, G. (2018). What are the taxpayer savings from cancelling the visas of organised crime offenders? Australian Institute of Criminology.

Morgan, A., Dowling, C., \& Voce, I. (2020). Australian outlaw motorcycle gang involvement in violent and organised crime (No. 586; Trends \& Issues in Crime and Criminal Justice). Australian Institute of Criminology. https://aic.gov.au/publications/tandi/tandi586

Nagin, D. S., \& Farrington, D. P. (1992). The Onset and Persistence of Offending. Criminology, 30(4), 501-524. https://doi.org/10.1111/j.1745-9125.1992.tb01114.x

Ostrosky, F., Borja, K. C., Rebollar, C. R., \& Galván, K. X. D. (2012). Neuropsychological profiles of members of organized crime and drug-traffic organizations. Research and Reports in Forensic Medical Science, 2, 19-30. https://doi.org/10.2147/RRFMS.S32352

Paoli, L. (2003). Mafia brotherhoods: Organized crime, Italian style. Oxford University Press.

Paoli, L. (2014). The Italian Mafia. In L. Paoli (Ed.), The Oxford Handbook of Organized Crime (pp. 121-141). Oxford University Press.

Pedersen, M. L. (2018). Do offenders have distinct offending patterns before they join adult gang criminal groups? Analyses of crime specialization and escalation in offence seriousness. European Journal of Criminology, 15(6), 680-701. https://doi.org/10.1177/1477370817751351

Piquero, A. R., Oster, R. P., Mazerolle, P., Brame, R., \& Dean, C. W. (1999). Onset Age and Offense Specialization. Journal of Research in Crime and Delinquency, 36(3), 275-299. https://doi.org/10.1177/0022427899036003002

Pyrooz, D. C., \& Densley, J. A. (2016). Selection into Street Gangs: Signaling Theory, Gang Membership, and Criminal Offending. Journal of Research in Crime and Delinquency, 53(4), 447-481. https://doi.org/10.1177/0022427815619462

Pyrooz, D. C., Turanovic, J. J., Decker, S. H., \& Wu, J. (2016). Taking Stock of the Relationship Between Gang Membership and Offending: A Meta-Analysis. Criminal Justice and Behavior, 43(3), 365-397. https://doi.org/10.1177/0093854815605528

Raby, C., \& Jones, F. (2016). Identifying risks for male street gang affiliation: A systematic review and narrative synthesis. The Journal of Forensic Psychiatry \& Psychology, 27(5), 601644. https://doi.org/10.1080/14789949.2016.1195005 
Requena, L., de Juan, M., Salinas, A. G., \& de la Corte, L. (2014). A psychosocial study on crime and gender: Position, role and status of women in a sample of Spanish criminal organizations / Un estudio psicosocial sobre la delincuencia y género. Posición, rol y estatus de la mujer en una muestra española de organizaciones criminales. International Journal of Social Psychology, 29(1), 121-149.

https://doi.org/10.1080/02134748.2013.878572

Salinas, A. G., \& Regadera, S. F. (2016). Multiple affiliations in criminal organizations: Analysis of a Spanish sample. Crime, Law and Social Change, 65(1), 47-65. https://doi.org/10.1007/s10611-015-9597-z

Savona, E. U., Calderoni, F., Superchi, E., Comunale, T., Campedelli, G. M., Marchesi, M. E., \& Kamprad, A. (2017). Systematic review of the social, psychological and economic factors relating to criminalisation and recruitment to OC (pp. 5-71) [Report on factors relating to OC]. UCSC-Transcrime. https://www.projectproton.eu/wpcontent/uploads/2018/01/D1.1-Report-on-factors-relating-to-OC.pdf

Sergi, A. (2016). A qualitative reading of the ecological (dis)organisation of criminal associations. The case of the 'Famiglia Basilischi' in Italy. Trends in Organized Crime, 19(2), 149-174. https://doi.org/10.1007/s12117-015-9254-z

Sergi, A. (2018). Widening the Antimafia Net: Child Protection and the Socio-Cultural Transmission of Mafia Behaviours in Calabria. Youth Justice, 18(2), 149-168. https://doi.org/10.1177/1473225418791420

Sharpe, E. G. (2002). Negotiating with Gang Members. Journal of Police Crisis Negotiations, 2(2), 35-48. https://doi.org/10.1300/J173v02n02_05

Slade, E. P., Stuart, E. A., Salkever, D. S., Karakus, M., Green, K. M., \& Ialongo, N. (2008). Impacts of age of onset of substance use disorders on risk of adult incarceration among disadvantaged urban youth: A propensity score matching approach. Drug and Alcohol Dependence, 95(1-2), 1-13. https://doi.org/10.1016/j.drugalcdep.2007.11.019

Smith, D. C. (1975). The Mafia mystique. Basic Books.

Smith, R. G. (2014). Responding to organised crime through intervention in recruitment pathways. Trends and Issues in Crime and Criminal Justice, 473, 1.

Spapens, T., \& Moors, H. (2020). Intergenerational transmission and organised crime. A study of seven families in the south of the Netherlands. Trends in Organized Crime. https://doi.org/10.1007/s12117-019-09363-w

Steffensmeier, D. J., \& Ulmer, J. T. (2005). Confessions of a Dying Thief: Understanding Criminal Careers and Illegal Enterprise. Transaction Aldine.

Sullivan, C. J., Mcgloin, J. M., Pratt, T. C., \& Piquero, A. R. (2006). Rethinking the "norm" of offender generality: Investigating specialization in the short-term. Criminology, 44(1), 199233. https://doi.org/10.1111/j.1745-9125.2006.00047.x 
Tremblay, R. E., Japel, C., Perusse, D., Mcduff, P., Boivin, M., Zoccolillo, M., \& Montplaisir, J. (1999). The search for the age of 'onset' of physical aggression: Rousseau and Bandura revisited. Criminal Behaviour and Mental Health, 9(1), 8-23.

https://doi.org/10.1002/cbm.288

Van der Geest, V., Van Koppen, M. V., \& Kleemans, E. R. (2020). Delinquent Development, Employment and Income in a Sample of Dutch Organized Crime Offenders: Shape, Content, and Correlates of Delinquent Trajectories from Age 12 to 65. In D. Weisburd, E. U. Savona, B. Hasisi, \& F. Calderoni (Eds.), Understanding Recruitment to Organized Crime and Terrorism (pp. 309-335). Springer International Publishing. https://doi.org/10.1007/9783-030-36639-1_13

Van Dijk, M., Kleemans, E., \& Eichelsheim, V. (2019). Children of Organized Crime Offenders: Like Father, Like Child? An Explorative and Qualitative Study Into Mechanisms of Intergenerational (Dis)Continuity in Organized Crime Families. European Journal on Criminal Policy and Research, 25(4), 345-363. https://doi.org/10.1007/s10610-018-93816

Van Koppen, M. V. (2013). Involvement mechanisms for organized crime. Crime, Law and Social Change, 59(1), 1-20. https://doi.org/10.1007/s10611-012-9396-8

Van Koppen, M. V., \& De Poot, C. J. (2013). The truck driver who bought a café: Offenders on their involvement mechanisms for organized crime. European Journal of Criminology. https://doi.org/10.1177/1477370812456346

Van Koppen, M. V., De Poot, C. J., \& Blokland, A. A. J. (2010). Comparing Criminal Careers of Organized Crime Offenders and General Offenders. European Journal of Criminology, 7(5), 356-374. https://doi.org/10.1177/1477370810373730

Van Koppen, M. V., De Poot, C. J., Kleemans, E. R., \& Nieuwbeerta, P. (2010). Criminal Trajectories in Organized Crime. The British Journal of Criminology, 50(1), 102-123. https://doi.org/10.1093/bjc/azp067

Varese, F. (2017). What is organised crime. In S. Carnevale, S. Forlati, \& O. Giolo (Eds.), Redefining Organised Crime: A Challenge for the European Union? Hart Publishing.

Von Lampe, K. (2016). Organized Crime: Analyzing Illegal Activities, Criminal Structures, and Extra-legal Governance. SAGE.

Wolfowicz, M., Litmanovitz, Y., Weisburd, D., \& Hasisi, B. (2019). A Field-Wide Systematic Review and Meta-analysis of Putative Risk and Protective Factors for Radicalization Outcomes. Journal of Quantitative Criminology. https://doi.org/10.1007/s10940-01909439-4

Wright, K. A., Pratt, T. C., \& DeLisi, M. (2008). Examining Offending Specialization in a Sample of Male Multiple Homicide Offenders. Homicide Studies, 12(4), 381-398. https://doi.org/10.1177/1088767908323930 
Wu, J., Hu, X., \& Orrick, E. A. (2021). The Relationship between Motivations for Joining Gangs and Violent Offending: A Preliminary Test on Self-Determination Theory. Victims \& Offenders, O(0), 1-15. https://doi.org/10.1080/15564886.2021.1898508

\section{Tables}

\section{Tables.docx}

$35 \mathrm{~KB}$

\section{Footnotes}

1.

The PMM dataset was developed within the framework of the research project PROTON, funded by the European Union's Horizon 2020 research and innovation program under grant agreement number 699824.

2.

Mafia offenses include mafia association (Article 416-bis of the Italian Criminal Code (CC)), electoral deal between politics and mafia (Article 416-ter of the CC), assistance to the associates (Article 418 of the $\mathrm{CC}$ ), and any other offense aggravated by the use of the mafia method for the purpose of benefiting a mafia association (now under art. 416-bis 1 of the CC, previously Art. 7 of Decree Law 152/1991 converted into Art. 7 of law 203/1991). Most of the offenders included in the data set had received a conviction for mafia association (Article 416-bis of the CC), which is a specific type of criminal association introduced into the Italian Criminal Code in 1982. A mafia association is a criminal association whose members use the intimidatory power of the association and the consequent conditions of subjection and silence (so-called omertà) to commit serious offenses and obtain unjust advantages (La Spina, 2014, p. 594).

3.

For each criminal conviction, the original PMM data set included detailed information on the legislative source, article number, and also the paragraph of the violated provision. With the aim of extracting more synthetic information on the type of committed crime, we classified the offenses into 30 crime categories according to the 
content and purpose of the violated provision and the type of criminal offense (i.e., felony or misdemeanor).

4.

Statutory penalties may differ at the paragraph level of the provision, effectively yielding more than 40,000 distinct types of violations in terms of their seriousness. It was impossible to determine the statutory penalty for all of them, but starting from most frequent offenses the seriousness was assigned to approximately $95 \%$ of the total offenses in the PMM data set. The remaining offenses have a missing seriousness value.

5.

The PMM lacks information on the day and month of each crime, thus impeding establishment of the order of crimes committed in the same year. To avoid any measurement error, we decided to exclude from the pre-mafia career all non-mafia offenses committed in the same year as the mafia offense.

6.

The diversity index for individual $i\left(D I_{i}\right)$ was defined as follows $\$: D I \_\{\mathrm{i}\}=1-\backslash$ sum_\{m $=$ $1\}^{\wedge}\{30\}\left\{p_{-}\{m\}^{\wedge}\{i\}^{*}\right\} p_{-}\{m\}^{\wedge}\{i\} \backslash \$$ where $m=1,2, \ldots, 30$ are the 30 crime categories identified in the data set (see Table A.2 in the Supplementary Materials) and $p_{m}{ }^{i}$ is the proportion of offenses committed by individual $i$ in the crime category $m$, considering only the criminal career before recruitment.

7.

The escalation parameter was missing in three cases: for offenders who committed only one crime, for offenders who committed only two or more crimes in the same year, and for offenders who committed crimes in different years, but with missing seriousness scores leading to seriousness availability in less than two years.

8.

Alternative models that require continuous dependent variables, such as Ordinary Least Squares regression, would have raised two issues. First, without a meaningful division of the sample into distinct categories (i.e. early and late recruits), we would have encountered difficulties in interpreting the results of the models in the absence of 
a clear threshold, thus leaving many problems of definition and of theoretical contribution fully unsolved. Second, OLS would have been more prone to possible bias in the exact determination of the year of recruitment as discussed above. Conversely, logistic regression makes it possible to derive more easily interpretable estimations by comparing two 'extreme' macro-categories. 